\title{
ENDODONTIJOJE NAUDOJAMŲ DANTŲ ŠAKNIES KANALŲ MINKŠTŲJŲ UŽPILDŲ DAROMA İTAKA STIKLO PLUOŠTO KAIŠČIŲ RETENCINEI JËGAI
}

\author{
Paulina Grinkevičiūtė $\dot{1}^{1}$ Eglè Šinkūnaitėe ${ }^{2}$ Monika Zaleckyte் \\ 'Odontologijos klinika ,, Gerdenta”, '2Odontologijos klinika ,Orto Vita”, \\ ${ }^{3}$ Lietuvos sveikatos moksly universiteto Medicinos akademijos Odontologijos fakultetas, \\ Dantu ir žandikauliu ortopedijos klinika
}

Raktažodžiai: stiklo pluošto kaištis (SPK), dantų šaknų kanalų minkštieji užpildai (DŠKMU), adhezija, retencija.

\begin{abstract}
Santrauka
Pagrindinis endodontinio gydymo tikslas yra užpildyti dantų šaknų kanalus trimatèje erdvejje, kad išvengtume kanalų reinfekcijos ir apsaugotume viršūninio apydančio audinius. Svarbu paminèti, kad ne tik kanalų apikalinès dalies, bet ir vainikinès dalies sandarumas yra svarbus endodontinio gydymo sèkmei. Šio darbo tikslas buvo įvertinti, susisteminti ir išanalizuoti mokslinejje literatūroje pateikiamus duomenis apie endodontijoje naudojamų DŠKMU itaką SPK retencinėms savybėms. Šioje sisteminejje apžvalgoje išanalizuoti 6 pilno teksto straipsniai. Remiantis atrinktų straipsnių rezultatų duomenimis, galime teigti, kad epoksidinių dervų turintys DŠKMU pasižymi aukštesne retencine jèga nei kitų grupių DŠKMU. Pastebèta, kad aukštesnè retencinè jèga gaunama tada, kai SPK cementuojamas ne iš karto po endodontinio gydymo, o praejus $7-15$ dienų, arba 6 mènesiams. Labiausiai retencinès jègos praradimui turi įtakos DŠKMU pasirinkimas ir SPK cementavimo laikas, o ne cemento rūšis.
\end{abstract}

\section{Ivadas}

Stiklo pluošto kaiščiai yra plačiai naudojami restauracinèje odontologijoje dèl panašių elastinių savybių su dentinu bei geresnio jejgos ir įtampu pasiskirstymo nei metaliniu kaiščiu [1]. SPK sėkmingas panaudojimas dalinai priklauso nuo pasirinktos cementavimo procedūros protokolo. Šiuolaikiniai derviniai cementai gali būti suskirstyti $i$ tris pogrupius, priklausomai nuo danties paviršiaus paruošimo prieš cementavimą (1 lentelè) $[2,3]$.
SPK cementavimo procedūra yra jautri ịvairiems veiksniams, tokiems kaip: dentino užteršimas, kaiščio paviršiaus paruošimas, medžiagų susitraukimas, polimerizacijos reakcijos ypatumai [4]. Endodontijoje dantų šaknų kanalų plombavimui naudojami minkštieji užpildai (MU) taip pat turi įtakos stiklo pluošto su dentinu sukibimui sumažinti [5].

Idealus dantų šaknų kanalų minkštasis užpildas turètų sukurti efektyvų surišimą tarp kaiščio medžiagos ir dentino, kad būtų išvengta pralaidumo. Taip pat DŠKMU turi būti netoksiškas ir gydyti viršūninio apydančio pažeidimus [6]. Rinkoje gausu dantų šaknų kanalų MU, pagal jų cheminę sudèti jie skirstomi ị grupes. Epoksidinès dervos (ED) pagrindu pagaminti DSSKMU yra mègstami dèl gerų fizikinių savybių ir biologinio suderinamumo [7]. Kalcio hidroksido pagrindu pagaminti DŠKMU stimuliuoja šaknies viršūninio trečdalio biologinį užsidarymą, kas padidina gydymo sẻkmę. DŠKMU cinko oksido ir eugenolio (COE) pagrindu dažnai tampa pirmu pasirinkimu tarp odontologų dèl ilgalaikių, sèkmingų gydymo rezultatų [5]. Vienuose tyrimuose teigiama, kad eugenolis kenkia polimerizacijai $[8,9]$, tačiau yra ir tam prieštaraujančių tyrimų, nurodančių, kad nèra skirtumo tarp eugenolio turinčių ir neturinčių minštujų užpildų daromos itakos SPK retencijai [10-12]. Manoma, kad eugenolis kontaktuoja su derviniu pagrindu pagamintomis medžiagomis. Minkštuosiuose užpilduose esantis eugenolis gali sureaguoti su laisvais radikalais ir taip inhibuoti polimerizacijos reakciją $[13,14]$, sumažinti susijungimo jègą bei klinikinę restauracijos sèkmę $[15,16]$.

Biokeramikos (BC) pagrindu pagaminti minkštieji užpildai yra sąlygiškai naujos medžiagos ir yra mažai studijų apie šių minkštųjų užpildų daromą ịtaką stiklo pluošto cementavimui, nors ir nustatyta, kad surišimo jèga tarp dentino ir gutaperčos su endosequence BC biokeraminiu minkštuoju užpildu yra panaši kaip ir naudojant gutaperča kartu su $\mathrm{AH}$ 
1 lentelè.

\begin{tabular}{|c|c|c|c|}
\hline Cemento rūšis & \multicolumn{3}{|c|}{ Cementavimo protokolas } \\
\hline Dervinis cementas & $\begin{array}{l}\text { 1) } 15 \mathrm{~s} \text { aplikuojama } 35 \% \text { fosforo } \\
\text { rūgštis, plaunama vandeniu } 15 \mathrm{~s} \text {, } \\
\text { sausinama oru, vandens perteklius } \\
\text { pašalinamas sauskaiščiais }\end{array}$ & $\begin{array}{l}\text { 2) Mikrošepetėliu } 20 \\
\text { s įtrinamas surišiklis, } \\
\text { švelnia oro srove nusau- } \\
\text { sinamas, perteklius } \\
\text { pašalinmas sauskaiščiais }\end{array}$ & $\begin{array}{l}\text { 3) Cementas ịterpiamas ị paruoštą } \\
\text { šaknies kanalą bei aplikuojmas ant } \\
\text { SPK prieš jo ịterpimą i kanalą, ki- } \\
\text { etinama } 40 \mathrm{~s} .600 \mathrm{~mW} \mathrm{~cm} 2 \text { helio } \\
\text { lempa }\end{array}$ \\
\hline $\begin{array}{l}\text { Savièsdinantis der- } \\
\text { vinis cementas }\end{array}$ & $\begin{array}{l}\text { 1) Mikrošėpetèliu } 30 \text { s ịtrinamas } \\
\text { surišiklis (priklausomai nuo litera- } \\
\text { tūros, gali būti vadinamas praim- } \\
\text { eriu), švelniai oro srove nusau- } \\
\text { sinamas, perteklius pašalinamas } \\
\text { sauskaiščiais }\end{array}$ & \multicolumn{2}{|c|}{$\begin{array}{l}\text { 2) Cementas ịterpiamas ị paruoštą šaknies kanalą bei aplikuo- } \\
\text { jamas ant SPK prieš jo ịterpimą ị kanalą, kietinama } 40 \mathrm{~s} 600 \\
\mathrm{~mW} \mathrm{~cm} 2 \text { helio lempa }\end{array}$} \\
\hline $\begin{array}{l}\text { Savisurišantis der- } \\
\text { vinis cementas }\end{array}$ & \multicolumn{3}{|c|}{$\begin{array}{l}\text { Cementas ịterpiamas tiesiogiai ị šaknies kanalą, po to - SPK ir paliekama } 5 \mathrm{~min} \text {. automatiniam - } \\
\text { cheminiam sukietejjimui, paskui kietinama } 40 \mathrm{~s} 600 \mathrm{~mW} \mathrm{~cm} 2 \text { helio lempa. }\end{array}$} \\
\hline
\end{tabular}

\begin{tabular}{|l|l|}
\hline Straipsnių įtraukimo kriterijai & Straipsnių atmetimo kriterijai \\
\hline Straipsniai ne senesni nei 5 metų & Publikacijos senesnės nei 5 metų \\
\hline Straipsniai anglų kalba & Straipsniai publikuoti ne anglų kalba \\
\hline $\begin{array}{l}\text { Tyrimai atlikti su universalia tes- } \\
\text { tavimo mašina }\end{array}$ & Nepilno teksto publikacijos \\
\hline Publikuojamų tyrimų tipas: in vitro & $\begin{array}{l}\text { Publikacijos yra literatūros apžvalga } \\
\text { ar in vivo tyrimas }\end{array}$ \\
\hline Išstūmimo jèga pateikta (MPa) & Išstūmimo jèga nèra pateikta (Mpa) \\
\hline $\begin{array}{l}\text { Tyrimui naudoti dvigubo kietèjimo } \\
\text { arba } \\
\text { savaiminio surišimo cementai }\end{array}$ & \\
\hline
\end{tabular}

minkštuoju užpildu [17].

Laikas, naudojant adhezinius dervinius cementus, kada yra cementuojamas SPK, taip pat yra svarbus surišimo jègai. Tyrimai tiksliai nenurodo, ar po endodontinio gydymo SPK turètų būti cementuojami iš karto, ar praejjus tam tikram laiko tarpui. Manoma, kad naudojant DŠKMU eugenolio pagrindu SPK cementavimas neturètų būti atliekamas iškart po endodontinio gydymo. Taip yra todèl, kad po tam tikro laiko eugenolis susigeria ị šaknies dentiną ir sumažina dentino užterštumą. Dèl to galima išgauti stipresnę adhezinę jungtị tarp SPK, dentino ir naudojamų dervinių cementų [18]. Kitame tyrime teigiama, kad eugenolis laikui begant ir toliau skverbiasi ị dentino tubules ir taip susilpnina adheziją [19].

Darbo uždaviniai: palyginti skirtingų DŠKMU daromą įtaką jègai, reikalingai išstumti SPK, išsiaiškinti, ar laikotarpis, kada vyksta SPK cementavimas po endodontinio kanalo gydymo, keičia kaiščio išstūmimo jẻgos pokytị, ištirti SPK naudojamo cemento daromą itaką adhezijai naudojant skirtingų rūšių DŠKMU.

Darbo tikslas: ịvertinti, susisteminti, išanalizuoti mokslinèje literatūroje pateikiamus duomenis apie endodontijoje naudojamų DŠKMU įtaką SPK retencinėms savybėms.

\section{Medžiaga ir metodai}

Mokslinès literatūros apžvalga atlikta taikant PRISMA atrankos kriterijus. Mokslinės publikacijos ieškotos duomenų 1a lentelè. Straipsnių atrankos grafikas. Straipsnių atranka: sisteminei apžvalgai atrinkti 6 straipsniai.

Atlikus straipsnių paiešką identifikuoti 234 straipsniai: Medline (42), Science Direct (192)

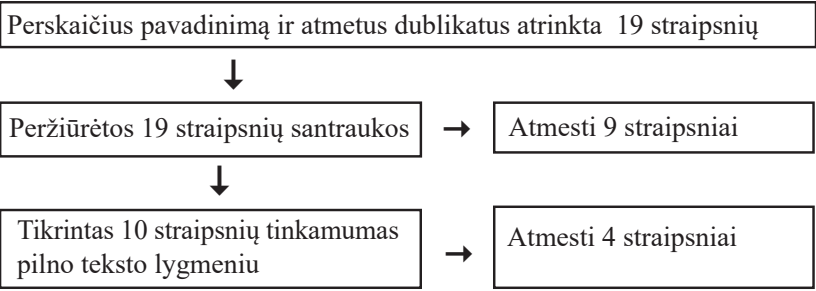

bazėse: PubMed, ScienceDirect. Prieš pradedant mokslinès literatūros analizę trys tyrejjai susipažino su straipsnių apžvalgos protokolu bei itraukimo ir atmetimo kriterijais. Mokslinių publikacijų paieška rẻmėsi raktiniais žodžiais ir žodžių junginiais. Naudoti raktiniai žodžiai ir jų kombinacijos: fiber post, push-out bond strength, sealers. Ar straipsniai atitinka atrankos kriterijus sprende trys tyrejjai, o kilę nesutarimai išspręsti diskutuojant. Paieška pradèta 2018m. rugsẻjo 12d., baigta $2018 \mathrm{~m}$. gruodžio $16 \mathrm{~d}$. (1a lentelè).

\section{Rezultatai}

Šioje sisteminèje apžvalgoje išanalizuoti 6 pilno teksto straipsniai [20-25]. Visi duomenys apie atrinktus straipsnius pateikiami 2 lenteleje. Tyrimuose dažniausiai naudojami mineralinio trioksido agregato (MTA), ED arba COE pagrindu pagaminti DŠKMU. SPK cementavimui rinktasi dvigubo kietèjimo derviniai cementai su trijų žingsnių surišimo sistema arba savièsdinantys dvigubo kietejimo derviniai cementai. Straipsniuose SPK cementavimo protokolas skirstomas į: 1) neatidèliotinas, kai SPK cementuojamas per pirmają parą po dantų šaknų kanalų gydymo DŠKMU, 2) atokusis, kai SPK cementuojamas per 7-15 dienų po dantų šaknų kanalų gydymo DŠKMU, 3) tolimasis, kai SPK cementuojamas po 
6 mènesių.

Remiantis atrinktu straipsnių rezultatu duomenimis, galime teigti, kad ED turintys MU pasižymi aukštesne retencine jèga nei kitu grupių DŠKMU. Tokie rezultatai stebimi 5-iuose straipsniuose. Tik vienas straipsnis [22] nerado statistiškai reikšmingo skirtumo tarp COE ir ED turinčių DŠKMU. Iš visų atrinktų straipsnių tik vienas straipsnis $i \mathfrak{t y -}$ rimą įtraukè BC dalelių turinti MU. Rezultatai parodè, jog šis DŠKMU pasižymi aukštesne retencine jèga lyginant su COE pagrindu DŠKMU, tačiau nepakankamai, kad būtų pranašesnis už ED turintị DŠKMU.

Apibendrinti rezultatai parodè (3 lentelè), kad naudojant ED pagrindu pagamintą DŠKMU laiko intervalas, kada cementuosime SPK reikšmingai skiriasi. Pastebèta, kad aukštesnè retencinè jèga gaunama tada, kai SPK cementuojamas ne iš karto po endodontinio gydymo, o praejjus 7,15 dienų arba 6 mènesiams. Retencinès jègos sumažèjimas dažniausiai pasireiškia COE pagrindu esančiuose DŠKMU, ypač tuomet, jeigu SPK cementavimas atidedamas vèlesniam laikui [20]. Gauta, kad skirtingas SPK cementavimo laikas retencinès jègos pokyčiams neigiamos įtakos neturèjo, kai kanalams plombuoti buvo naudojami MTA, BC ir COE pagrindu pagaminti DŠKMU [24,23,22].

\section{Diskusija}

SPK cementavimui yra naudojami skirtingų rūšiu derviniai cementai, kurie dar labiau pagerina fizikines pačių kaiščių savybes [26, 27]. SPK kartu su šaknies kanalo sienomis po cementavimo procedūros sudaro vienatūị kompleksą, taigi, kaiščių retencija priklauso nuo sąveikos tarp šakninio dentino, cemento ir kaiščio paviršiaus [28]. Atsicementavimas pažymimas kaip dažniausia kaiščių komplikacija ir įvyksta būtent viename iš tų paviršių, kuriuose liečiasi su kietaisiais danties audiniais [29].

Mūsų atliktoje tyrimų apžvalgoje, kurioje siekėme išsiaiškinti skirtingų endodontinių MU

2 lentelè.

\begin{tabular}{|c|c|c|c|c|c|c|}
\hline & Tyrimas & $\begin{array}{l}\text { Tyrimo } \\
\text { imtis }\end{array}$ & $\begin{array}{l}\text { Minkštieji šaknų } \\
\text { kanalų užpildai }\end{array}$ & Cementai & $\begin{array}{c}\text { Kanalo } \\
\text { plombavimo } \\
\text { metodika }\end{array}$ & Tyrimo grupès \\
\hline 1. & $\begin{array}{l}\text { Bohrer ir kt., } \\
\text { Brazilija, } 2018\end{array}$ & $\begin{array}{c}180 \text { jaučio } \\
\text { dantų }\end{array}$ & $\begin{array}{c}\text { Endofil (Dentsply } \\
\text { Maillefer, Šveicarija) } \\
\text { AHplus (Dentsply } \\
\text { Maillefer, Šveicarija ) }\end{array}$ & $\begin{array}{l}\text { Relyx U200 (3M } \\
\text { ESPE, JAV) } \\
\text { Multilink Automix } \\
\text { (Ivoclar Vivadent, } \\
\text { Lichtenšteinas) }\end{array}$ & $\begin{array}{l}\text { Lateralinès } \\
\text { kondensacijos } \\
\text { būdu }\end{array}$ & $\begin{array}{c}\text { A:Endofill+Relyx } \\
\text { B:Endofill+Multilink } \\
\text { C: AH plus+ Relyx } \\
\text { D: AH plus+ Mul- } \\
\text { tilink }\end{array}$ \\
\hline 2. & $\begin{array}{l}\text { Reyhani ir kt., } \\
\text { Iranas, } 2015\end{array}$ & $\begin{array}{c}72 \\
\text { viršutiniai } \\
\text { kandžiai }\end{array}$ & $\begin{array}{l}\text { AH plus (Dentsplay, } \\
\text { Vokietija) } \\
\text { Dorifill (Dorident, } \\
\text { Vokietija) } \\
\text { MTA Fillapex (Ange- } \\
\text { lus Solucoesodonto- } \\
\text { logica, Brazilija) }\end{array}$ & $\begin{array}{l}\text { Clearfil (Kuraray } \\
\text { Japonija) }\end{array}$ & $\begin{array}{l}\text { Lateralinès } \\
\text { kondensacijos } \\
\text { būdu }\end{array}$ & $\begin{array}{l}\text { A: MTA Fillapex } \\
\text { B: AH plus } \\
\text { C: Dorifill } \\
\text { D: kontrole }\end{array}$ \\
\hline 3. & $\begin{array}{l}\text { Ruiz ir kt., Bra- } \\
\text { zilija, } 2017\end{array}$ & $\begin{array}{c}56 \\
\text { viršutiniai } \\
\text { kandžiai }\end{array}$ & $\begin{array}{c}\text { Endofill (Dentsplay, } \\
\text { Brazilija) } \\
\text { SEALER } \\
\text { 26(Dentsplay, Bra- } \\
\text { zilija) }\end{array}$ & $\begin{array}{l}\text { Variolink II (Ivoclar } \\
\text { Vivadent, Lichten- } \\
\text { šteinas) } \\
\text { Relyx U200 (3M } \\
\text { ESPE, JAV) }\end{array}$ & $\begin{array}{l}\text { Vertikalios } \\
\text { kondensacijos } \\
\text { būdu }\end{array}$ & $\begin{array}{c}\text { A: Endofill + Vario- } \\
\text { link II } \\
\text { B: Endofill + } \\
\text { RelyX U200 } \\
\text { C: Sealer } 26+ \\
\text { Variolink II } \\
\text { D: Sealer } 26+ \\
\text { RelyX U200 }\end{array}$ \\
\hline 4. & $\begin{array}{l}\text { Rosa ir kt., } \\
\text { Brazilija, } 2013\end{array}$ & $\begin{array}{l}60 \text { jaučio } \\
\text { dantų }\end{array}$ & $\begin{array}{c}\text { Endofil (Dentsply } \\
\text { Maillefer, Šveicarija) } \\
\text { MTA Fillapex, } \\
\text { Angelus, Brazilija) } \\
\text { AHplus (Dentsply } \\
\text { Maillefer, Šveicarija ) }\end{array}$ & $\begin{array}{l}\text { Allcem (FGM, } \\
\text { Brazilija) }\end{array}$ & $\begin{array}{l}\text { Lateralinès } \\
\text { kondensacijos } \\
\text { būdu }\end{array}$ & $\begin{array}{l}\text { A: Endofill } \\
\text { B: MTA } \\
\text { C: AH plus }\end{array}$ \\
\hline 5. & $\begin{array}{l}\text { Vilas-Boas ir } \\
\text { kt., Vokietija, } \\
2017\end{array}$ & 84 kapliai & $\begin{array}{c}\text { Endofil (Dentsply } \\
\text { Maillefer, Šveicarija) } \\
\text { Endosequence (Bras- } \\
\text { seler JAV) } \\
\text { AH plus (Dentsplay, } \\
\text { Vokietija) }\end{array}$ & $\begin{array}{c}\text { RelyX'TMARC ( } 3 \mathrm{M} \\
\text { ESPE, JAV) }\end{array}$ & $\begin{array}{l}\text { Vertikalios } \\
\text { kondensacijos } \\
\text { būdu }\end{array}$ & $\begin{array}{c}\text { A:AH plus } \\
\text { B:BC } \\
\text { C:EN }\end{array}$ \\
\hline 6. & $\begin{array}{l}\text { Aleisa ir kt., } \\
\text { Saudo Arabija, } \\
2013\end{array}$ & 54 kapliai & $\begin{array}{c}\text { Endofil } \\
\text { (Promedica,Vokietija) } \\
\text { AH26 (Dentsply } \\
\text { DeTrey Gmbh, } \\
\text { Vokietija) } \\
\text { Tubli-seal (Kerr, } \\
\text { Italija) } \\
\end{array}$ & $\begin{array}{l}\text { MultiCoret Flow } \\
\text { (Ivoclar Vivadent, } \\
\text { Lichtenšteinas) }\end{array}$ & $\begin{array}{l}\text { Lateralinès } \\
\text { kondensacijos } \\
\text { būdu }\end{array}$ & $\begin{array}{c}\text { A:AH26 } \\
\text { B:Endofill } \\
\text { C:Tubi-seal }\end{array}$ \\
\hline
\end{tabular}


itaką SPK cementavimo retencijai, pastebima tendencija, kad ED pagrindu pagaminti DŠKMU yra efektyvesni už COE pagrindu pagamintus DŠKMU, tačiau literatūroje nèra tikslaus bendro sutarimo, kaip COE pagrindo DŠKMU daro itaką surišimo jègai cementuojant SPK [30]. ED ir COE pagrindo DŠKMU sąveika gali būti paaiškinta pastarojo kietejjimo reakcijos eiga - cinko oksidas (milteliai) maišomi su eugenoliu (skysčiu) reaguodami sukuria cinko oksido eugenolato matriksą. Susidaręs junginys, paveiktas dentino tubulèse esančio skysčio, gali turèti grižtamąą reakciją, ir išskirti eugenoli iš matrikso [31], kuris skatina dervinio cemento polimerizacijos reakciją, taip sumažinant surišimo stiprumą tarp dentino ir SPK [32, 33]. Eugenolio molekulès hidrolinè grupè yra linkusi protonizuoti laisvus radikalus, kurie susidaro dervos polimerizacijos metu [34] ir taip sumažina surišimo jègą tarp dentino ir dervinès medžiagos [35].

Žinant problemą, kylančią dèl eugenolio pagrindo DŠKMU naudojimo, siekiama išsiaiškinti, kaip galima būtų pasiekti kuo geresnių rezultatų cementuojant SPK. Kanale esančio eugenolio pašalinimas tampa būtinybe, norint pagerinti adheziją. Siūlomos kelios išeitys [36]: dantų šaknų kanalų dezinfekavimas $70 \%$ etanoliu, rūgštinimas $37 \%$ fosforo rūgštimi bei mechaninis dalies dentino sluoksnio pašalinimas. $37 \%$ fosforo rūgštis pašalina užterštą sluoksnį ir sukelia demineralizaciją dentine iki 9-10 $\mu \mathrm{m}$. Naudojant èsdinimo - skalavimo sistemą, leidžiama efektyviau surišti eugenoliu užterštą dentino paviršių, lyginant su savièsdinančiomis sistemomis [37]. Hagge su bendraautoriais nustatè rūgšties panaudojimo reikšmingą poveikị eugenoliu gydytiems dantims: paviršiaus paveikimas fosforo rūgštimi yra veiksmingas atkuriant retenciją, kuri buvo paveikta eugenolio [38]. Tjan ir Nemetz pritardami teige, kad etanolio panaudojimas atneša nuoseklesnius ir patikimesnius rezultatus nei visiškai joks paviršiaus apdorojimas, o fosforo rūgšti ț rekomenduota aplikuoti 10s, nuplauti ir drégmès perteklių pašalinti sauskaisčiais [39].

3 lentelè.

\begin{tabular}{|c|c|c|c|c|c|c|c|c|}
\hline & Tyrimas & Tyrimo grupès & $\begin{array}{l}\text { Išstūmimo } \\
\text { jèga (MPa) } \\
\text { Iškart }\end{array}$ & $\begin{array}{l}\text { Išstūmimo } \\
\text { jèga (MPa) } \\
24 \mathrm{~h}\end{array}$ & $\begin{array}{l}\text { Išstūmimo } \\
\text { jèga (MPa) } \\
\text { Po } 1 \text { sav. }\end{array}$ & $\begin{array}{l}\text { Išstūmimo } \\
\text { jèga (MPa) } \\
\text { Po } 2 \text { sav. }\end{array}$ & $\begin{array}{l}\text { Išstūmimo } \\
\text { jèga (MPa) } \\
6 \text { mėn. }\end{array}$ & $\begin{array}{l}\text { Išstūmimo } \\
\text { jèga } \\
\text { (MPa) } \\
12 \text { mèn. }\end{array}$ \\
\hline 1. & $\begin{array}{l}\text { Bohrer ir kt., } \\
\text { Brazilija, } 2018\end{array}$ & $\begin{array}{l}\text { A:Endofill+Relyx } \\
\text { B:Endofill+Multilink } \\
\text { C: AH plus+ Relyx } \\
\text { D: AH plus+ Multilink }\end{array}$ & & $\begin{array}{l}\text { A: } 6,92 \\
\text { B: } 4,92,2 \\
\text { C: } 11,23,2 \\
\text { D:6,92,1 }\end{array}$ & & & $\begin{array}{l}\text { A: } 4,62,1 \\
\text { B: } 2,81,4 \\
\text { C: } 6,02,3 \\
\text { D: } 9,52,3\end{array}$ & $\begin{array}{l}\text { A: } 4,12,7 \\
\text { B: } 6,12,8 \\
\text { C: } 3,92,6 \\
\text { D: } 6,11,9\end{array}$ \\
\hline 2. & $\begin{array}{l}\text { Reyhani ir kt., } \\
\text { Iranas, } 2015\end{array}$ & $\begin{array}{l}\text { A: MTA Fillapex } \\
\text { B: AH plus } \\
\text { C: Dorifill } \\
\text { D: kontrole }\end{array}$ & $\begin{array}{l}\text { A: } 2.24(0.02) \\
\text { B: } \\
2.08(0.02) \\
\text { C: } 1.02(0.03) \\
\text { D: } 4.45(0.09)\end{array}$ & & & & & \\
\hline 3. & $\begin{array}{l}\text { Ruiz ir kt., } \\
\text { Brazilija, } 2017\end{array}$ & $\begin{array}{l}\text { A: Endofill + Variolink II } \\
\text { B: Endofill + RelyX U200 } \\
\text { C: Sealer 26 + Variolink II } \\
\text { D: Sealer 26 + RelyX U200 }\end{array}$ & & & $\begin{array}{l}\text { A: } 10.38(1.71) \\
\text { B: } 11.75(2.03) \\
\text { C: } 12.16(1.73) \\
\text { D: } 11.34(1.14) \\
\end{array}$ & & $\begin{array}{l}\text { A: } 12.39(3.09) \\
\text { B: } 12.83(0.94) \\
\text { C: } 12.37(1.29) \\
\text { D: } 13.77(2.47)\end{array}$ & \\
\hline 4. & $\begin{array}{l}\text { Rosa ir kt., } \\
\text { Brazilija, } 2013\end{array}$ & $\begin{array}{l}\text { A: Endofill } \\
\text { B: MTA } \\
\text { C: AH plus }\end{array}$ & $\begin{array}{l}\text { A: } 1.7 \pm 1.1 \\
\text { B: } 1.7 \pm 0.6 \\
\text { C: } 2.8 \pm 1.4\end{array}$ & & & $\begin{array}{l}\text { A: } 1.6 \pm 1.0 \\
\text { B: } 2.5 \pm 2.2 \\
\text { C: } 4.3 \pm 1.4\end{array}$ & & \\
\hline 5. & $\begin{array}{l}\text { Vilas-Boas ir } \\
\text { kt., Vokietija, } \\
2017\end{array}$ & $\begin{array}{l}\text { A:AH plus } \\
\text { B:BC } \\
\text { C:EN }\end{array}$ & $\begin{array}{l}\text { A:21,20 }(5,79) \\
B: 10,43(5,89) \\
C: 9,75(3,17)\end{array}$ & & $\begin{array}{l}\text { A: } 15,54(4,98) \\
\text { B: } 13,15(4,36) \\
\text { C: } 5,73(2,82)\end{array}$ & & & \\
\hline 6. & $\begin{array}{l}\text { Aleisa ir kt., } \\
\text { Saudo Arabija, } \\
2013\end{array}$ & $\begin{array}{l}\text { A:AH26 } \\
\text { B:Endofil } \\
\text { C:Tubi-seal }\end{array}$ & & $\begin{array}{l}\text { A: } 271.5678 .4 \\
\text { B: } 92.1631 .8 \\
\text { C: } 105.6645 .3\end{array}$ & & & & \\
\hline
\end{tabular}


Atsižvelgiant ị laikotarpị, praëjusį po DŠKMU ịterpimo ị kanalą iki SPK cementavimo procedūros, gali būti skirstoma ị ankstyvujji (per pirmą parą), atokuji (7-14d .) ir tolimajji (6mèn.). Pastebeta, kad kaiščio vietos formavimą ir cementavimą atlikus po endodontinio gydymo praejus ne mažiau kaip 24 val, surišimas yra stipresnis, palyginus rezultatus, gautus kaištį cementuojant iš karto po endodontinio gydymo $[18,40]$. Leidus eugenoliniam DŠKMU sukietèti, sumažèja užterštumas juo. Menezes su bendraautoriais rezultatai pritarè pastarajam tyrimui bei pastebèjo, kad ruošiant kanalą SPK cementavimui įmanoma pašalinti iki $0,4 \mathrm{~mm}$ dentino sluoksnio, kuris būna impregnuotas DŠKMU [41]. Šiai hipotezei nepritare Izadi su bendraautoriais, kurie pateikè priešingus rezultatus: kuo ilgesnis laikas praeina nuo endodontinio gydymo iki SPK cementavimo, tuo daugiau eugenolio ịsiskverbia ị dentino tubules ir dèl to blogina retenciją. Už tai jie laiko atsakingą eugenolio sudètyje esančią fenolio grupę, kuri gali ịsiskverbti giliai ị šakninị dentiną [42]. Tačiau, neatsižvelgiant ị laiką, praejusị po endodontinio gydymo, galima daryti išvadą, kad eugenolis bet kuriuo atveju mažina surišimo jègą tarp dervinio cemento ir danties kietujų audinių.

Norint pagerinti gydymo sèkmès rodiklį, svarbiausia suprasti medžiagų tarpusavio sąveiką. COE pagrindu pagaminti DŠKMU sumažina SPK, cementuoto derviniu cementu, retenciją kanale, nepriklausomai nuo naudojamos surišimo sistemos ar dervinio cemento rūšies. Taigi, siūlome vengti šių minkštųų užpildų, jei planuojama danties restauracijai naudoti dervinio pagrindo medžiagas.

\section{Išvados}

Nèra skirtumo, kurị cementą pasirinksite cementuojant SPK. Tai gali būti dvigubo kietejjimo derviniai cementai su trijų žingsnių surišimo sistema arba savièsdinantys dvigubo kietejjimo derviniai cementai. Labiausiai retencinès jègos praradimui turi įtakos DŠKMU pasirinkimas ir SPK cementavimo laikas, o ne cemento rūšis. Geriausia, kad cementuojant SPK būtų praejjusios 7 - 15 dienų ir endodontinio kanalo užpildymui naudotumète ED pagrindu pagamintus DŠKMU.

\section{Literatūra}

1. Santos AF, Meira JB, Tanaka CB, Xavier TA, Ballester RY, Lima RG. Can fiber posts increase root stresses and reduce fracture? J Dent Res 2010;89:587-591. https://doi.org/10.1177/0022034510363382

2. Macedo VC, Faria e Silva AL \& Marcondes Martins LR. Effect of cement type, relining procedure, and length of cementation on pull-out bond strength of fiber posts. Journal of Endodontics 2010; 36(9), 1543-1546.

https://doi.org/10.1016/j.joen.2010.04.014
3. Radovic, I., Mazzitelli, C., Chieffi, N., \& Ferrari, M. (2008). Evaluation of the adhesion of fiber posts cemented using different adhesive approaches. European Journal of Oral Sciences 116(6), 557-563. https://doi.org/10.1111/j.1600-0722.2008.00577.x

4. De Sousa Menezes M, Queiroz EC, Soares PV, Faria-e-Silva AL, Soares CJ, Martins LR. Fiber post etching with hydrogen peroxide: effect of concentration and application time. J Endod 2011;37:398-402.

https://doi.org/10.1016/j.joen.2010.11.037

5. Demiryürek EO, Külünk S, Yüksel G, Saraç D, Bulucu B. Effects of three canal sealers on bond strength of a fiber post. J Endod 2010;36(3):497-501. https://doi.org/10.1016/j.joen.2009.11.014

6. Kumar SA, Shivanna V, Naian MT, Shivamurthy GB. Comparative evaluation of the apical sealing ability and adaptation to dentine of three resin-based sealers: An in vitro study. Journal of Conservative Dentistry 2011; 14(1): 16-20.

https://doi.org/10.4103/0972-0707.80724

7. Tagger M, Tagger E, Tjan AHL. et al. Measurement of adhesion of endodontic sealers to dentine. J Endod 2002;28:351-4. https://doi.org/10.1097/00004770-200205000-00001

8. Baldissara P, Zicari F, Valandro LF. et al. Effect of root canal treatments on quartz fiber posts bonding to root dentin. J Endod. 2006;32:985-8.

https://doi.org/10.1016/j.joen.2006.04.013

9. Burns DR, Moon PC, Webster NP. et al. Effect of endodontic sealers on dowels lute with resin cement. J Prosthodont 2000;9:137-41.

https://doi.org/10.1053/jopr.2000.19167

10. Hagge MS, Wong RD, Lindemuth JS. Retention strengths of five luting cements on prefabricated dowels after root canal obturation with a zinc oxide/eugenol sealer: Dowel space preparation/cementation at one week after obturation. J Prosthodont 2002; 11:168-75.

https://doi.org/10.1053/jopr.2002.127619

11. Mannocci F, Ferrari M, Watson TF. Microleakage of endodontically treated teeth restored with fiber posts and composite cores after cyclic loading: a confocal microscopic study. J Prosthet Dent 2001;85:284-91.

https://doi.org/10.1067/mpr.2001.113706

12. Davis ST, O'Connell BC. The effect of two root canal sealers on the retentive strength of glass fibre endodontic posts. J Oral Rehabil 2007; 34:468-73.

https://doi.org/10.1111/j.1365-2842.2006.01649.x

13. al-Wazzan KA, al-Harbi AA, Hammad IA. The effect of eugenol-containing temporary cement on the bond strength of two resin composite core materials to dentin. J Prosthodont 1997; 6:37-42.

https://doi.org/10.1111/j.1532-849X.1997.tb00063.x

14. Schwartz R, Davis R, Hilton TJ. Effect of temporary cements on 
the bond strength of a resin cement. Am J Dent 1992; 5:147-50.

15. Koch T, Peutzfeldt A, Malinovskii V. et al. Temporary zinc oxide-eugenol cement: eugenol quantity in dentin and bond strength of resin composite. Eur J Oral Sci 2013;121:363-9. https://doi.org/10.1111/eos.12053

16. Mosharraf R, Zare S. Effect of the type of endodontic sealer on the bond strength between fiber post and root wall dentin. J Dent 2014;11:455-63.

17. Shokouhinejad N, Gorjestani H, Nasseh AA, Hoseini A, Mohammadi M, Shamshiri AR. Push-out bond strength of gutta-percha with a new bioceramic sealer in the presence or absence of smear layer. Aust Endod J 2013; 39:102-106. https://doi.org/10.1111/j.1747-4477.2011.00310.x

18. Vano M, Cury AH, Goracci C. The effect of immediate versus delayed cementation on the retention of different types of fiber post in canals obturated using a eugenol sealer. J Endod 2006;32:882-885.

https://doi.org/10.1016/j.joen.2006.02.025

19. Aleisa K, Al-Dwairi ZN, Alsubait SA, Morgano SM. Pullout retentive strength of fiber posts cemented at different times in canals obturated with a eugenol-based sealer. J Prosthet Dent 2016;116:85-90.

https://doi.org/10.1016/j.prosdent.2015.12.010

20. Bohrer TC, Fontana PE, Wandscher VF, Morari VHC, Dos Santos SS, Valandro LF, Kaize OB.Endodontic sealers affect the bond strength of fiber posts and the degree of conversion of two resin cements. J Adhes Dent 2018;20(2):165-172.

21. Reyhani FM, Ghasemi N, Rahimi S, Milani AS, Omrani E. Effect of different endodontic sealers on the push-out bond strength of fiber post. Iran Endod J 2016;11(2):119-23.

22. Ruiz L, Gomes GM, Bittencourt B, da Silva RF, Gomes MM, Filho JCC, Calixto AL. Effect of root canal sealers on bond strength of fiber posts to root dentin cemented after one week or six months. Iran Endod J 2018; 13(1): 54-60.

23. Rosa RA, Barreto MS, Moraes Rdo A, Broch J, Bier CA, Só MV, Kaizer OB, Valandro LF. Influence of endodontic sealer composition and time of fiber post cementation on sealer adhesiveness to bovine root dentin. Braz Dent J 2013; 24(3):241-6. https://doi.org/10.1590/0103-6440201302154

24. Vilas-Boas DA, Grazziotin-Soares R, Ardenghi DM, Bauer J, de Souza PO, de Miranda Candeiro GT, Maia-Filho EM1, Carvalho CN. Effect of different endodontic sealers and time of cementation on push-out bond strength of fiber posts. Clin Oral Investig 2018;22(3):1403-1409.

https://doi.org/10.1007/s00784-017-2230-Z

25. AlEisa K, Al-Dwairi ZN, Lynch E, Lynch CD. In vitro evaluation of the effect of different endodontic sealers on retentive strength of fiber posts. Oper Dent 2013;38(5):539-44. https://doi.org/10.2341/12-414-L

26. Ferracane JL, Stansbury JW, Brke FJ. Self-adhesive resin cements - chemistry, properties and clinical considerations. J Oral Rehabil 2011;38:295-314. https://doi.org/10.1111/j.1365-2842.2010.02148.x

27. Mazzoni A, Marchesi G, Cadenaro M, Mazzotti G, Di Lenarda R, Ferrari M, Breschi L. Push-out stress fotr fiber posts luted using different adhesive strategies. Eur J Oral Sci 2009; 117:447-453.

https://doi.org/10.1111/j.1600-0722.2009.00656.x

28. Wegner PK, Freitag S, Kern M. Survival rate of endodontically treated teeth with posts after prosthetic restoration. J Endod 2006;32:928-931.

https://doi.org/10.1016/j.joen.2006.06.001

29. Aggarwal V, Singla M, Miglani S, Kohli S. Effect of different root canal obturating materials on push-out bond strength of a fiber dowel. J Prosthet 2012; 21:389-92.

https://doi.org/10.1111/j.1532-849X.2012.00850.x

30. Altmann ASP, Leitune VCB \& Collares FM. Influence of eugenol-based sealers on push-out bond strength of fiber post luted with resin cement: systematic review and meta-analysis. Journal of Endodontics 2015;41(9), 1418-1423.

https://doi.org/10.1016/j.joen.2015.05.014

31. Gomes GM, Gomes OM, Reis A, Gomes JC, Loguercio AD, Calixto AL. Regional bond strengths to root canal dentin of fiber posts luted with three cementation systems. Braz Dent J 2011; 22(6):460-7.

https://doi.org/10.1590/S0103-64402011000600004

32. Dibaji F, Mohammadi E, Farid F, Mohammadian F, Sarraf P, Kharrazifard MJ. The effect of bc sealer, ah-plus and dorifill on push-out bond strength of fiber post. Iran Endod J 2017; 12(4):443-8.

33. Dias LL, Giovani AR, Silva Sousa YT, Vansan LP, Alfredo E, Sousa- Neto MD, Paulino SM. Effect of eugenol-based endodontic sealer on the adhesion of intraradicular posts cemented after different periods. J Appl Oral Sci 2009;17(6):579-83. https://doi.org/10.1590/S1678-77572009000600008

34. Markowitz K, Moynihan M, Liu M, Kim S. Biologic properties of eugenol and zinc oxide-eugenol. A clinically oriented review. Oral Surg Oral Med Oral Pathol 1992;73(6):729-37. https://doi.org/10.1016/0030-4220(92)90020-Q

35. Fujisawa S, Kadoma Y. Action of eugenol as a retarder against polymerization of methyl methacrylate by benzoyl peroxide. Biomaterials 1997;18(9):701-3.

https://doi.org/10.1016/S0142-9612(96)00196-2

36. Aleisa K, Alghabban R, Alwazzan K, Morgano SM. Effect of three endodontic sealers on the bond strength of prefabricated fiber posts luted with three resin cements. J Prosthet 2012;107;322-6.

https://doi.org/10.1016/S0022-3913(12)60084-5

37. Powers JM, Finger WJ, \& Xie J. Bonding of composite resin to contaminated human enamel and dentin. Journal of Prosthodontics 1995;4 28-32

https://doi.org/10.1111/j.1532-849X.1995.tb00311.x

38. Hagge MS, Wong RD, \& Lindemuth JS. Effect of three root 
canal sealers on the retentive strength of endodontic posts luted with resin cement International Endodontic Journal 2002;35 372-378.

https://doi.org/10.1046/j.0143-2885.2001.00493.x

39. Tjan AH, \& Nemetz H. Effect of eugenol-containing endodontic sealer on retention of prefabricated posts luted with an adhesive composite resin cement. Quintessence International 1992:23 839-834.

40. Jalalzadeh SM, Mamavi A, Abedi H, Mashouf RY, Modaresi A, Karapanou V. Bacterial microleakage and post space timing for two endodontic sealers: an in vitro study. J Mass Dent Soc 2010; 59(2):34- 7.

41. Menezes MS, Queiroz EC, Campos RE, et al. Influence of endodontic sealer cement on fibreglass post bond strength to root dentine. Int Endod J 2008;41:476-84.

https://doi.org/10.1111/j.1365-2591.2008.01378.x

42. Izadi A, Azarsina M, Kasraei S. Effect of eugenol-containing sealer and post diameter on the retention of fiber reinforced composite posts. JCD 2013;16:61-4.

\section{THE EFFECT OF DIFFERENT ENDODONTIC SEALERS FOR FIBER POSTS RETENTIVE STRENGTH}

P.Grinkevičiūtè, E.Šinkūnaitė, M.Zaleckytè hesion. ey words: fiber post, sealers, push-out bond strength, ad-
Summary

The ultimate goal of endodontic treatment is to fill the root canals in 3D space to avoid reinfection and treat periapical lesion. For the success of endodontic treatment it is important to seal not only the apical third of the canals but also the coronal third. The purpose of this work was to evaluate, systematize and analyze the data presented in the scientific literature the effect of endodontic sealers for fiber posts retention properties. This systematic review analyzes 6 full-text articles. Based on the results of the selected articles, we can say that sealers containing epoxy resins has a higher retention force than other groups of fiber posts. It has been observed that higher retention force is obtained when fiber post is cemented not immediately after endodontic treatment but 7 to 15 days or 6 months after canal treatment. The greatest loss of retention force is influenced by the choice of sealer and the time of cementing the fiber post rather than the type of cement.

Correspondence to: sinkunaite.egle@gmail.com

Gauta 2019-03-06 